\title{
Treatment of 5 dogs with immune- mediated thrombocytopenia using Romiplostim
}

\author{
Barbara Kohn ${ }^{1}$, Gürkan Bal ${ }^{2}$, Aleksandra Chirek', Sina Rehbein ${ }^{1}$ and Abdulgabar Salama ${ }^{2 *}$
}

\begin{abstract}
Background: Immune thrombocytopenia (ITP) in dogs is analogous to that in humans. Romiplostim, a novel thrombopoietin receptor (TPO-R) agonist, is currently used for the treatment of refractory ITP in humans, but not in dogs. Here, we describe the response to romiplostim in five dogs with refractory ITP. Five dogs with severe and refractory ITP (three primary and two secondary) received romiplostim subcutaneously. Four dogs were administered $3-5 \mu \mathrm{g} / \mathrm{kg}$ and one dog received 10-13 $\mu \mathrm{g} / \mathrm{kg}$ body weight once weekly.

Results: Romiplostim was well-tolerated and administration was associated with an increase in platelet counts in all five dogs. Four of the five dogs entered remission and relapses were not observed over a follow-up period of 3-10 months.

Conclusions: Romiplostim is effective in the treatment of ITP in dogs at least as well as in humans. This finding may help to develop and use new therapeutics for ITP in dogs and humans.
\end{abstract}

Keywords: Immune thrombocytopenia, ITP, Dog, Romiplostim, Thrombopoietin, mpl

\section{Background}

Immune thrombocytopenia (ITP) is a well-characterized autoimmune bleeding disease in humans that is accompanied by the immune-mediated destruction of platelets and impaired thrombopoiesis [1-4]. Comparable to humans, dogs develop ITP spontaneously [5] or secondary following infectious or neoplastic diseases [6-8]. Differential diagnosis of ITP in both species is based on the exclusion of known causes or underlying diseases [5, 9].

The current treatment options for ITP in humans and dogs are largely identical. Corticosteroid administration is generally accepted as the first-line treatment option in affected human patients and dogs $[10,11]$. However, the effect of steroids is not predictable in a single patient [12]. Approximately two-thirds of human patients achieve a complete or partial response with corticosteroids, although a high proportion of patients relapse and

\footnotetext{
* Correspondence: abdulgabar.salama@charite.de

${ }^{2}$ Institut für Transfusionsmedizin, Charité - Universitätsklinikum,

Augustenburger Platz 1, 13353 Berlin, Germany

Full list of author information is available at the end of the article
}

require alternative therapy [13]. Similarly, steroid treatment may remain ineffective and may result in severe adverse reactions in dogs $[8,10,14-16]$.

A second line therapy in dogs is not well-defined and may include platelet transfusions and high dose intravenous immunoglobulins (IVIgG) for acute management, or vincristine, azathioprine, mycophenolate mofetil, cyclophosphamide, cyclosporine, danazol, leflunomide, and ultimately splenectomy for long-term management and in cases of relapse or refractory ITP $[8,10,16-19]$. These treatment options are not performed analogously and there are no generally accepted guidelines on when they should be used [16]. The rates of relapse and mortality in dogs range between $9 \%$ and $43 \%[8,10,15,18,20-22]$.

During the last decade, significant new aspects regarding the pathogenesis and treatment of ITP in humans have been highlighted. Patients with ITP have been found to have increased platelet destruction due to autoantibodies and an impaired thrombopoiesis in the bone marrow [3, 23]. Consequently, two thrombopoietin receptor (TPO-R) agonists, romiplostim and eltrombopag, have been shown to be effective in the treatment of human ITP [24]. Romiplostim is a $59 \mathrm{kDa}$ peptibody that 
binds to the extracellular domain of TPO-R on megakaryocytes and platelets, activates the receptor, and increases platelet counts [25]. In contrast, eltrombopag is a small molecule with a molecular weight of $442 \mathrm{Da}$, and is a non-peptide TPO-R agonist that selectively binds to the transmembrane domain of the TPO-R and increases platelet counts [26]. The safety and efficiency of TPO agonists in the treatment of ITP has been previously studied in well-designed controlled and randomized clinical trials. Eltrombopag is administered orally at a dosage ranging between 25 and $75 \mathrm{mg} / \mathrm{d}$, and 1-10 $\mu \mathrm{g} / \mathrm{kg}$ romiplostim is administered subcutaneously once weekly [22, 27-29]. Treatment with TPO agonists is usually indicated in patients with refractory ITP and in patients who do not adequately respond to standard therapy [22, 27].

Dogs with therapy refractory ITP are at a high risk of life-threatening bleeding. In such cases, there are no alternative therapeutic options, and affected dogs either die or are euthanized due to thrombocytopenia [5]. As ITP in dogs is largely analogous to ITP in humans, we questioned whether human TPO agents such as the Food and Drug Administration (FDA) approved human TPO-R agonists can be used as a new therapeutic measure in dogs with ITP that cannot be controlled by standard therapy.

\section{Methods}

Five dogs with primary or secondary ITP were admitted to the Small Animal Clinic at the Freie Universität Berlin between 10/2014 and 6/2015 and were treated with romiplostim. Inclusion criteria were diagnosed primary or secondary ITP based on complete medical records, platelet counts $<150,000 / \mu \mathrm{l}$ and a positive plateletbound antibody test. Primary ITP was only diagnosed, if there was no evidence of any other underlying disease or cause which might have triggered platelet destruction. In presence of an additionally positive direct Coombs' test, Evans' syndrome was diagnosed. Discrimination of primary and secondary forms of ITP was based on the complete diagnostic work-up that comprised of a complete blood count, blood smear evaluation, testing for erythrocyte agglutination, clinical chemistry, coagulation panel, diagnostic imaging including thoracic and abdominal radiography and ultrasonography, direct and indirect tests for infectious diseases, and immunological testing $[7,8]$. The dogs had been pre-treated with prednisolone and adjunctive immunosuppressive drugs and were either non-responders or were readmitted due to a relapse. A response to therapy (complete remission) was defined as an increase of the platelet count to $\geq 150,000$ / $\mu \mathrm{l}$. A relapse was defined as a decrease of the platelet count below $150,000 / \mu \mathrm{l}$ after the value had already been within reference range. A dog was classified as nonresponder when, the platelet counts did not increase or did not reach values above $150.000 / \mu l$.(references) The dosage for each dog was extrapolated from human data, and was dependent on the clinical responses [30]. Consent from the owners was obtained. Romiplostim is licensed in human medicine and a comparable product is not available in veterinary medicine. Therefore this drug can be used in veterinary medicine without approval of an ethics committee. Moreover all the dogs were treated using standard therapy (best practice of veterinary care) first before using this novel agent.

\section{Results}

Depending on the availability of romiplostim and the severity of ITP in affected dogs, treatment was initially commenced with a dosage of $3-5 \mu \mathrm{g} / \mathrm{kg}$ per week. Prior to treatment with romiplostim, all dogs had underwent conventional treatment (Tables 1 and 2) and had experienced one or more relapses. Treatment was either ineffective or was discontinued to avoid the development of severe side effects (e.g. in the case of ehrlichiosis). Administration of romiplostim resulted in an increase of platelet counts within 3-6 days following the commencement of treatment in 4 of the 5 treated dogs (Table 2). The remaining dog suffered from ehrlichiosis and hepatopathy, and did not respond to the administration of $5.3 \mu \mathrm{g} / \mathrm{kg}$ of romiplostim. Bone marrow examination revealed the presence of numerous megakaryocytes. A dose escalation was attempted after the following 2 months and the dog received first $13 \mu \mathrm{g} / \mathrm{kg}$ and then $10 \mu \mathrm{g} / \mathrm{kg}$ after one week. Simultaneously, prednisolone was re-administered due to the deterioration of hepatopathy. One week after the second injection, an increase in platelet counts was observed (Table 2). We report here a mean length of treatment of 13.8 ( $\min .3$, max. 35 and median 11 weeks) weeks, which were varying for each individual dog. None of the treated dogs developed any side effects. Concomitant therapy with other drugs was gradually reduced and halted in three of the dogs when the platelet count was stabilized. Interestingly, none of the five dogs relapsed during observation. Moreover, the initially given dose of romiplostim could be reduced in four cases (Table 2).

\section{Discussion}

ITP is the most common cause of severe thrombocytopenia in dogs [31]. Corticosteroids are considered as the cornerstone of treatment. However, in cases where these drugs remain ineffective, contraindicated, or may cause severe side effects, other treatment options are desirable $[8,16,32]$. Furthermore, dogs are, unlike humans, unable to verbally express themselves. Therefore, the true incidence of intolerability to immunosuppressive drugs remains obscure in the treated animals.

Romiplostim is produced by covalently linking two tandem dimers to the C-terminus of endogenous TPO. Thus, exposure of cells expressing TPO-R (BaF3-mpl) to 
Table 1 Signalment and history of five dogs with primary and secondary immune thrombocytopenia treated with romiplostim

\begin{tabular}{|c|c|c|c|c|c|}
\hline Dog & Signalment & $\begin{array}{l}\text { ITP - diagnoses } \\
\text { month/year }\end{array}$ & Recurrences & $\begin{array}{l}\text { Previous } \\
\text { immunosuppressive therapy }\end{array}$ & $\begin{array}{l}\text { Therapy (in addition to } \\
\text { immunosuppressive } \\
\text { medication) }\end{array}$ \\
\hline 1 & $\begin{array}{l}\text { Bearded Collie } \\
7 \text {-year-old, female } \\
22 \mathrm{~kg}\end{array}$ & 7/2012: primary ITP & $\begin{array}{l}\text { 1) } 10 / 2012 \\
\text { 2) } 3 / 2013 \\
\text { 3) } 9 / 2014 \\
\text { 4) } 10 / 2014\end{array}$ & $\begin{array}{l}\text { pred } 1 \mathrm{mg} / \mathrm{kg} \text { twice daily + } \\
\text { MMF } 8 \mathrm{mg} / \mathrm{kg} \text { twice daily } \\
\text { Recurrence 1) Pred, } \\
\text { cyclosporine } \\
\text { 2) only pred } \\
\text { 3) pred, MMF, then } \\
\text { dexamethasone } \\
\text { 4) pred, MMF }\end{array}$ & $\begin{array}{l}\text { omeprazole, sucralfate } \\
\text { (to prevent } \\
\text { gastrointestinal ulcers) } \\
\text { ursodeoxycholic acid } \\
\text { (due to increase in liver } \\
\text { enzymes) }\end{array}$ \\
\hline 2 & $\begin{array}{l}\text { Border Collie } \\
10 \text {-year-old, female-spayed } \\
25 \mathrm{~kg} \text { (obese) }\end{array}$ & $\begin{array}{l}\text { 2014: primary AlHA } \\
\text { 5/2015: Evans' } \\
\text { syndrome (primary } \\
\text { ITP and AlHA) }\end{array}$ & after 3 weeks & $\begin{array}{l}\text { short-acting methyl-pred } \\
10 \mathrm{mg} / \mathrm{kg} \text { once, pred } \\
0.8 \mathrm{mg} / \mathrm{kg} \text { twice daily }\end{array}$ & $\begin{array}{l}\text { doxycycline } \\
\text { omeprazole, sucralfate }\end{array}$ \\
\hline 3 & $\begin{array}{l}\text { Poodle } \\
3 \text {-year-old, male-neutered } \\
25 \mathrm{~kg}\end{array}$ & $\begin{array}{l}\text { 12/2014: Evans' } \\
\text { syndrome (primary } \\
\text { ITP and AlHA) }\end{array}$ & after 3 weeks & $\begin{array}{l}\text { pred } 1.5 \mathrm{mg} / \mathrm{kg} \text { twice daily, } \\
\text { MMF } 5 \mathrm{mg} / \mathrm{kg} \text { twice daily }\end{array}$ & omeprazole, sucralfate \\
\hline 4 & $\begin{array}{l}\text { Mixed-breed } \\
\text { 3-year-old, female-spayed, } 22 \text { kg }\end{array}$ & $\begin{array}{l}\text { ITP associated with } \\
\text { monocytic } \\
\text { ehrlichiosis }\end{array}$ & after 4 weeks & pred $1 \mathrm{mg} / \mathrm{kg}$ twice daily & $\begin{array}{l}\text { doxycycline } \\
\text { omeprazole, sucralfate }\end{array}$ \\
\hline 5 & $\begin{array}{l}\text { Mixed-breed } \\
2.5 \text {-year-old, female } \\
14 \mathrm{~kg}\end{array}$ & $\begin{array}{l}\text { ITP associated with } \\
\text { monocytic } \\
\text { ehrlichiosis }\end{array}$ & 2 weeks & pred $0.4 \mathrm{mg} / \mathrm{kg}$ once daily & $\begin{array}{l}\text { chloramphenicole/ } \\
\text { imidocarb } \\
\text { amoxicillin-clavulanic } \\
\text { acid } \\
\text { omeprazole, sucralfate } \\
\text { ursodeoxycholic acid } \\
\text { S-adenosyl-methionine }\end{array}$ \\
\hline
\end{tabular}

Pred prednisolone, MMF mycofenolate mofetil, ITP immune thrombocytopenia, AIHA autoimmune hemolytic anemia

romiplostim results in rapid tyrosine phosphorylation of mpl, JAK2, and STAT5, and stimulation of megakaryopoiesis and platelet production. Pharmacodynamic studies in animals including mice, rats, rabbits, monkeys, and dogs have shown well-tolerability, and dose-dependent increases in platelet counts [24, 27, 33]. Subsequently, welldesigned human studies have been conducted in patients with chronic ITP. The drug was well-tolerated in all studies and most events were mild to moderate. Furthermore, there was no evidence of an increased risk of thromboembolic complications or development of antibodies against natural TPO. In 2008, romiplostim was licensed for the treatment of ITP in humans and long-term treatment appears to be well-tolerable [34-36].

Depending on the phylogenetic differences of TPO- $R$ in canines and humans, dual usage of TPO-R agonists in

Table 2 Romiplostim therapy in five dogs with primary and secondary immune thrombocytopenia: Dosage, response and outcome

\begin{tabular}{|c|c|c|c|c|c|c|c|}
\hline \multirow[t]{2}{*}{ Dog } & \multirow{2}{*}{$\begin{array}{l}\text { Current therapy at the } \\
\text { commencement of romiplostim }\end{array}$} & \multirow{2}{*}{$\begin{array}{l}\text { Platelets } \\
\text { count } \\
\times 10^{3} / \mu l\end{array}$} & \multirow{2}{*}{$\begin{array}{l}\text { Romiplostim } \\
\mu \mathrm{g} / \mathrm{kg} \\
\text { (initial dose) }\end{array}$} & \multicolumn{2}{|l|}{ Response } & \multirow{2}{*}{$\begin{array}{l}\text { Maintenance } \\
\text { therapy }\end{array}$} & \multirow[t]{2}{*}{ Outcome } \\
\hline & & & & Day & $\begin{array}{l}\text { Platelets } \\
\text { count } \\
\times 10^{3} / \mu l\end{array}$ & & \\
\hline 1 & $\begin{array}{l}\text { pred } 0.5 \mathrm{mg} / \mathrm{kg} \text { twice daily } \\
\text { MMF } 5 \mathrm{mg} / \mathrm{kg} \text { twice daily }\end{array}$ & 19 & 5 & $6 / 73$ & $13 / 226$ & $2.3 \mu \mathrm{g}$ romi & $C R>10$ mon \\
\hline 2 & pred $0.6 \mathrm{mg} / \mathrm{kg}$ twice daily & 57 & 3 & $\begin{array}{l}3 / 83 \\
5 / 131\end{array}$ & $\begin{array}{l}8 / 222 \\
15 / 332\end{array}$ & $\begin{array}{l}\text { now } 2 \mu \mathrm{g} / \mathrm{kg} \text { romi } \\
0.1 \mathrm{mg} / \mathrm{kg} \text { pred } \\
\text { every other day }\end{array}$ & $C R>3$ mon \\
\hline 3 & $\begin{array}{l}\text { pred } 0.6 \mathrm{mg} / \mathrm{kg} \text { twice daily } \\
\text { MMF } 5 \mathrm{mg} / \mathrm{kg} \text { twice daily }\end{array}$ & 25 & 5 & $\begin{array}{l}4 \\
7 \\
10\end{array}$ & $\begin{array}{l}58 \\
189 \\
217\end{array}$ & $2.5 \mu \mathrm{g}$ & $\begin{array}{l}\text { ITP CR } \\
\text { but euthanized due to } \\
\text { AlHA after } 2.5 \text { mon }\end{array}$ \\
\hline 4 & pred $0.5 \mathrm{mg} / \mathrm{kg}$ twice daily & 123 & 4.5 & $3 / 178$ & $5 / 213$ & 3.4 & $C R>5$ mon \\
\hline 5 & $\begin{array}{l}\text { a) pred } 0.4 \mathrm{mg} / \mathrm{kg} \text { once daily, doxycycline } \\
\text { b) } 2 \text { months later: pred } 0.5 \mathrm{mg} / \mathrm{kg} \text {, amoxicillin }\end{array}$ & $\begin{array}{l}\text { a) } 4 \\
\text { b) } 1\end{array}$ & $\begin{array}{l}\text { a) } 5.3 \\
\text { b) } 13\end{array}$ & $\begin{array}{l}\text { a) No response } \\
\text { b) } 4 \\
11 \\
15\end{array}$ & $\begin{array}{l}7 \\
3 \\
115\end{array}$ & & b) Lost for follow-up \\
\hline
\end{tabular}

Romi romiplostim, pred prednisolone, MMF mycofenolate mofetil, CR complete remission (platelet counts $>200 \times 10^{3} / \mu \mathrm{l}$ ), ITP immune thrombocytopenia, AlHA autoimmune hemolytic anemia, mon months

${ }^{a}$ due to autoimmune hemolysis 
both species may be evolutionally encouraging or discouraging. As shown in Fig. 1, TPO-R protein sequences of canines and humans are very highly conserved at the C-terminus and the possible binding site for TPO (EpoR-lig-bind domains) is localised in this highly conserved area. As romiplostim interacts with an extracellularly located part of TPO-R and canine and human protein sequences are highly conserved, this may be the molecular basis of this therapeutic effect in canine ITP. Consistently, the safety and haematological efficiency of recombinant human TPO peptide has been demonstrated in chemotherapy-induced thrombocytopenia in dogs [37]. To date, two TPO-R agonists, romiplostim and eltrombopag, have been approved by the FDA for the treatment of ITP in humans. Although both of these drugs activate TPO- $\mathrm{R}$ and are used for the same indications, their binding properties and their mode of action in activating TPO-R is rather different. In contrast to romiplostim, eltrombopag interacts with the transmembrane domain of TPO-R, where the protein sequences are not phylogenetically highly conserved. Therefore, we preferred to use romiplostim as a potential candidate drug for the treatment of ITP in dogs.
In this observational study, we treated five dogs with ITP with romiplostim. All five dogs appeared not only to tolerate the drug quite well, but four of the five dogs also responded relatively quickly with a significant increase of platelet counts. One dog with secondary ITP that had not responded to prednisolone and romiplostim at a dosage of $5 \mu \mathrm{g} / \mathrm{kg}$ responded to a higher dosage of romiplostim. Based on the dogs' medical history, the increase of platelet counts did not appear to be related to concomitant treatment with prednisolone.

One limitation of this pilot study is the low sample size and the inclusion of primary and secondary ITP forms. In some cases, contaminant immunosuppressive drugs was also necessary, at least, at the beginning of romiplostim therapy. Because of these limitations, dogs were treated with individual therapy protocol, inside of a clinical trial set-up. Depend on the duration of response, length of treatments were also varying for each individual dog. We report here a mean length of treatment of 13.8 weeks, whereas a mean treatment duration in human has been recently reported as 60 weeks and a maximum duration of 96 weeks [38]. Romiplostim dosage was reduced in 4 dogs (information is given in Table 2,

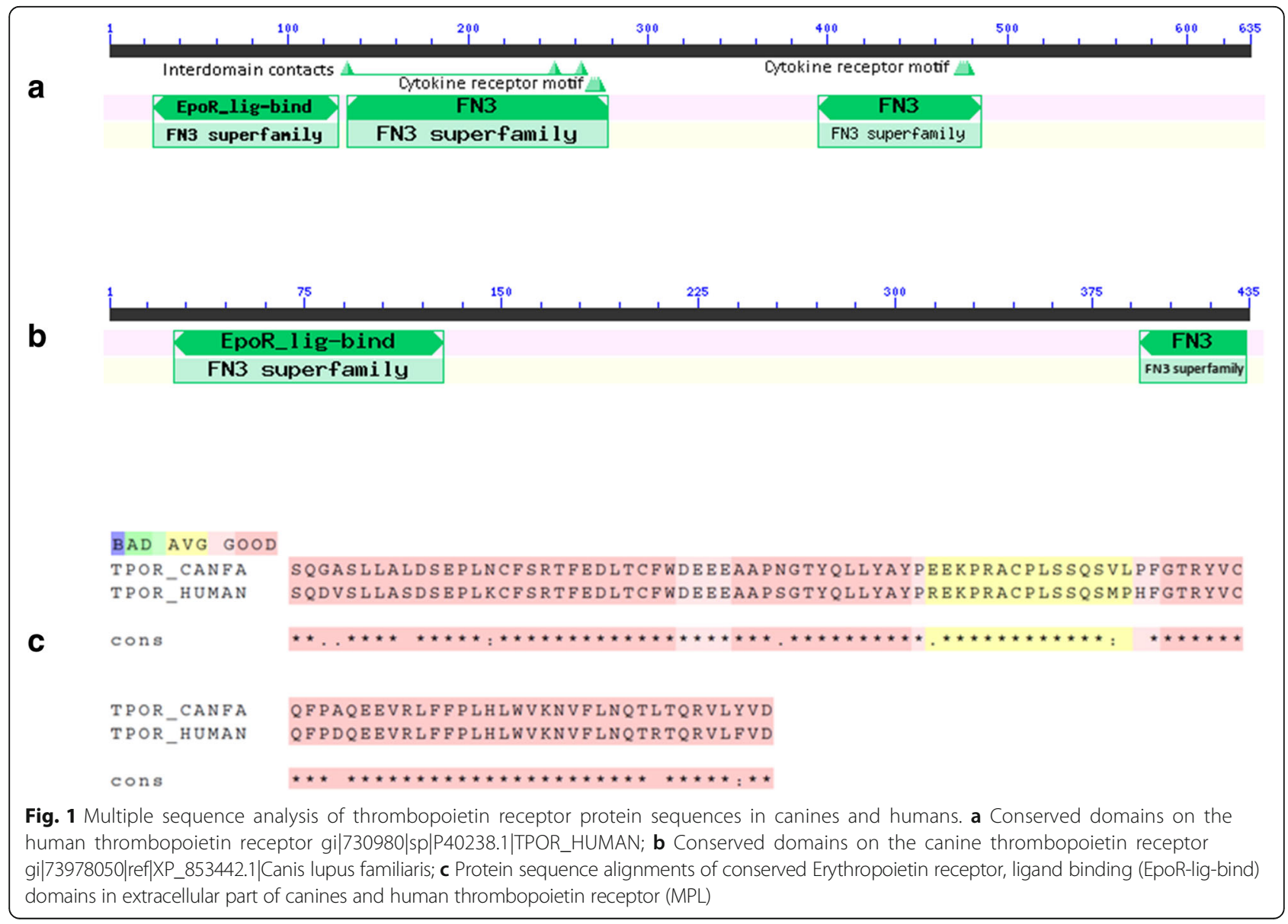


initial dose - maintenance dose). In 3 cases romiplostim was given until the end of the observation period, one case (no. 3) was euthanized, case no. 5 was lost for follow-up.

Interestingly, the start of the increase in platelets in treated dogs appears to occur within two days after the first administration. The question whether this effect would be faster via the administration of higher doses, i.e. initially $10 \mu \mathrm{g} / \mathrm{kg}$, remains to be answered in future studies. If this assumption would be true, romiplostim would be indicated as a first-line therapy in dogs requiring emergency treatment, i.e. dogs with life-threatening bleeding. The question why romiplostim appears to increase platelet counts in dogs faster than in humans remains obscure.

Romiplostim and other TPOs such as eltrombopag represent a new therapeutic measure for ITP in dogs that cannot be treated with conventional drugs or where these drugs are ineffective. Interestingly, the rapid effect is comparable with that observed in dogs treated with vincristine or IVIgG $[18,19]$.

Availability of romiplostim for usage in veterinary medicine may be limited by its high cost. We would therefore like to highlight one possible solution. The required amount of romiplostim for each human patient is dependent on the patient's response and is extremely variable. Some patients may require less than $100 \mu \mathrm{g}$, while others may require $>500 \mu \mathrm{g}$. Since the drug is only available in $250 \mu \mathrm{g}$ and $500 \mu \mathrm{g}$ vials, it cannot be avoided that the rest of the drug will be discarded. Based on our experience, the rest of the dissolved romiplostim can be stored for several weeks (6-8 weeks) under sterile conditions at $4{ }^{\circ} \mathrm{C}$ without a dramatic loss in biological activity. On the other hand, dogs need in total less amounts of the drug than humans. Thus, the available vials might be used in parallel for treatment of three or more dogs at the same time.

We presented here the results of a pilot study and showed that the approved human drug romiplostim may represent a novel therapeutic option in refractory dog ITP.

\section{Conclusions}

Romiplostim is effective in the treatment of ITP in dogs at least as well as in humans. This finding may help to develop and use new therapeutics for ITP in dogs and humans.

\section{Acknowledgements}

Not applicable.

\section{Funding}

This study was funded by the German Research Foundation (DFG) (Project number SA 405/3-1).
Availability of data and materials

The datasets supporting the conclusions of this article are included within the article and its additional files.

\section{Authors' contributions}

$\mathrm{GB}, \mathrm{BK}$ and $\mathrm{AS}$ conceived the study, analysed the data and wrote the paper; BK, AC, SR diagnosed and treated the dogs, and provided all relevant data. All authors critically revised the manuscript. All authors read and approved the final manuscript.

\section{Authors' information}

Not applicable.

\section{Competing interests}

The authors declare that they have no competing interests.

\section{Consent for publication}

Consent from the owners was obtained.

\section{Ethics approval and consent to participate}

Institutional review board approval was not required, as patients were treated with approved diagnostic and therapeutic procedures according to generally accepted standards of care. Concerning extralabel usage of romiplostim in dogs, Animal Welfare Officer of Freie Universität Berlin were informed. Accordingly with the provisions of 21 CFR 530, the FDA recognizes the professional judgment of veterinarians, and permits the extralabel use of drugs by veterinarians within the context of a valid veterinarian client-patient relationship (VCPR).

\section{Author details}

${ }^{1}$ FB Veterinärmedizin, Klinik für Kleine Haustiere, Freie Universität Berlin, Oertzenweg 19 b, 14163 Berlin, Germany. ${ }^{2}$ Institut für Transfusionsmedizin, Charité - Universitätsklinikum, Augustenburger Platz 1, 13353 Berlin, Germany.

Received: 17 November 2015 Accepted: 1 June 2016

Published online: 10 June 2016

\section{References}

1. Harrington WJ, Minnich V, Hollingsworth JW, Moore CV. Demonstration of a thrombocytopenic factor in the blood of patients with thrombocytopenic purpura. J Lab Clin Med. 1951;38(1):1-10.

2. Cines DB, Schreiber AD. Immune thrombocytopenia. Use of a Coombs antiglobulin test to detect IgG and C3 on platelets. N Engl J Med. 1979; 300(3):106-11.

3. Ballem PJ, Segal GM, Stratton JR, Gernsheimer T, Adamson JW, Slichter SJ. Mechanisms of thrombocytopenia in chronic autoimmune thrombocytopenic purpura. Evidence of both impaired platelet production and increased platelet clearance. J Clin Invest. 1987;80(1):33-40.

4. Cines DB, Bussel JB, Liebman HA, Luning Prak ET. The ITP syndrome: pathogenic and clinical diversity. Blood. 2009;113(26):6511-21.

5. Lewis DC, Meyers KM. Canine idiopathic thrombocytopenic purpura. J Vet Intern Med. 1996;10(4):207-18.

6. Lewis DC, Meyers KM, Callan MB, Bucheler J, Giger U. Detection of platelet-bound and serum platelet-bindable antibodies for diagnosis of idiopathic thrombocytopenic purpura in dogs. J Am Vet Med Assoc. 1995;206(1):47-52

7. Kohn B, Engelbrecht R, Leibold W, Giger U. Clinical findings, diagnostics and treatment results in primary and secondary immune-mediated thrombocytopenia in the dog. Kleintierpraxis. 2000;45(12):893-907.

8. Putsche JC, Kohn B. Primary immune-mediated thrombocytopenia in 30 dogs (1997-2003). J Am Anim Hosp Assoc. 2008;44(5):250-7.

9. Bussel JB, Cines D. Immune thrombocytopenic purpura, neonatal alloimmune thrombocytopenia and post-transfusion purpura. In: Hoffman EJB R, Shattil S, Furie B, Cohen HJ, Silberstein LE, editors. Hematology: Basic Principles and Practice. 3rd ed. 1999. p. 2096-114.

10. O'Marra SK, Delaforcade AM, Shaw SP. Treatment and predictors of outcome in dogs with immune-mediated thrombocytopenia. J Am Vet Med Assoc. 2011;238(3):346-52.

11. Provan D, Stasi R, Newland AC, Blanchette VS, Bolton-Maggs P, Bussel JB, Chong BH, Cines DB, Gernsheimer TB, Godeau B, et al. International 
consensus report on the investigation and management of primary immune thrombocytopenia. Blood. 2010;115(2):168-86.

12. Salama A. Current treatment options for primary immune thrombocytopenia. Expert Rev Hematol. 2011;4(1):107-18.

13. Force BCfSiHGHT. Guidelines for the investigation and management of idiopathic thrombocytopenic purpura in adults, children and in pregnancy. Br J Haematol. 2003;120(4):574-96.

14. Carr AP, Panciera DL, Kidd L. Prognostic factors for mortality and thromboembolism in canine immune-mediated hemolytic anemia: a retrospective study of 72 dogs. J Vet Intern Med. 2002;16(5):504-9.

15. Williams DA, Maggio-Price L. Canine idiopathic thrombocytopenia: clinical observations and long-term follow-up in 54 cases. J Am Vet Med Assoc. 1984;185(6):660-3.

16. Nakamura RK, Tompkins E, Bianco D. Therapeutic options for immunemediated thrombocytopenia. J Vet Emerg Crit Care (San Antonio). 2012;22(1):59-72.

17. Rozanski EA, Callan MB, Hughes D, Sanders N, Giger U. Comparison of platelet count recovery with use of vincristine and prednisone or prednisone alone for treatment for severe immune-mediated thrombocytopenia in dogs. J Am Vet Med Assoc. 2002;220(4):477-81.

18. Balog K, Huang AA, Sum SO, Moore GE, Thompson C, Scott-Moncrieff JC. A prospective randomized clinical trial of vincristine versus human intravenous immunoglobulin for acute adjunctive management of presumptive primary immune-mediated thrombocytopenia in dogs. J Vet Intern Med. 2013;27(3):536-41.

19. Bianco D, Armstrong PJ, Washabau RJ. A prospective, randomized, double-blinded, placebo-controlled study of human intravenous immunoglobulin for the acute management of presumptive primary immune-mediated thrombocytopenia in dogs. J Vet Intern Med. 2009;23(5):1071-8

20. Jackson ML, Kruth SA. Immune-mediated Hemolytic Anemia and Thrombocytopenia in the Dog: A retrospective study of 55 cases diagnosed from 1979 through 1983 at the Western College of Veterinary Medicine. Can Vet J. 1985;26(8):245-50.

21. Jans HE, Armstrong PJ, Price GS. Therapy of immune mediated thrombocytopenia. A retrospective study of 15 dogs. J Vet Intern Med. 1990;4(1):4-7.

22. Cines DB, Gernsheimer T, Wasser J, Godeau B, Provan D, Lyons R, et al. Integrated analysis of long-term safety in patients with chronic immune thrombocytopaenia (ITP) treated with the thrombopoietin (TPO) receptor agonist romiplostim. Int J Hematol. 2015;102(3):259-70.

23. Lev PR, Grodzielski M, Goette NP, Glembotsky AC, Espasandin YR, Pierdominici MS, Contrufo G, Montero VS, Ferrari L, Molinas FC, et al. Impaired proplatelet formation in immune thrombocytopenia: a novel mechanism contributing to decreased platelet count. Br J Haematol. 2014;165(6):854-64.

24. Kuter DJ. Thrombopoietin and thrombopoietin mimetics in the treatment of thrombocytopenia. Annu Rev Med. 2009;60:193-206.

25. Frederickson S, Renshaw MW, Lin B, Smith LM, Calveley P, Springhorn JP, Johnson K, Wang Y, Su X, Shen Y, et al. A rationally designed agonist antibody fragment that functionally mimics thrombopoietin. Proc Natl Acad Sci U S A. 2006;103(39):14307-12.

26. Jenkins JM, Williams D, Deng Y, Uhl J, Kitchen V, Collins D, Erickson-Miller CL Phase 1 clinical study of eltrombopag, an oral, nonpeptide thrombopoietin receptor agonist. Blood. 2007:109(11):4739-41.

27. Wang B, Nichol JL, Sullivan JT. Pharmacodynamics and pharmacokinetics of AMG 531, a novel thrombopoietin receptor ligand. Clin Pharmacol Ther. 2004;76(6):628-38.

28. Kuter DJ, Rummel M, Boccia R, Macik BG, Pabinger I, Selleslag D, Rodeghiero F, Chong BH, Wang X, Berger DP. Romiplostim or standard of care in patients with immune thrombocytopenia. N Engl J Med. 2010;363(20):1889-99.

29. Gonzalez-Porras JR, Mingot-Castellano ME, Andrade MM, Alonso R, Caparros I, Arratibel MC, Fernandez-Fuertes F, Cortti MJ, Pascual C, Sanchez-Gonzalez B, et al. Use of eltrombopag after romiplostim in primary immune thrombocytopenia. Br J Haematol. 2015;169(1):111-6.

30. Bussel JB, Kuter DJ, Pullarkat V, Lyons RM, Guo M, Nichol JL. Safety and efficacy of long-term treatment with romiplostim in thrombocytopenic patients with chronic ITP. Blood. 2009;113(10):2161-71.

31. Grindem CB, Breitschwerdt EB, Corbett WT, Jans HE. Epidemiologic survey of thrombocytopenia in dogs: a report on 987 cases. Vet Clin Pathol. 1991;20(2):38-43.
32. Yau VK, Bianco D. Treatment of five haemodynamically stable dogs with immune-mediated thrombocytopenia using mycophenolate mofetil as single agent. J Small Anim Pract. 2014;55(6):330-3.

33. Molineux G, Newland A. Development of romiplostim for the treatment of patients with chronic immune thrombocytopenia: from bench to bedside. Br J Haematol. 2010;150(1):9-20.

34. Newland A, Caulier MT, Kappers-Klunne M, Schipperus MR, Lefrere F, Zwaginga JJ, Christal J, Chen CF, Nichol JL. An open-label, unit dosefinding study of AMG 531, a novel thrombopoiesis-stimulating peptibody, in patients with immune thrombocytopenic purpura. $\mathrm{Br}$ J Haematol. 2006;135(4):547-53.

35. Kuter DJ, Bussel JB, Lyons RM, Pullarkat V, Gernsheimer TB, Senecal FM, Aledort LM, George JN, Kessler CM, Sanz MA, et al. Efficacy of romiplostim in patients with chronic immune thrombocytopenic purpura: a double-blind randomised controlled trial. Lancet. 2008:371(9610):395-403.

36. Chalmers S, Tarantino MD. Romiplostim as a treatment for immune thrombocytopenia: a review. J Blood Med. 2015;6:37-44.

37. Case BC, Hauck ML, Yeager RL, Simkins AH, de Serres M, Schmith VD, Dillberger JE, Page RL. The pharmacokinetics and pharmacodynamics of GW395058, a peptide agonist of the thrombopoietin receptor, in the dog, a large-animal model of chemotherapy-induced thrombocytopenia. Stem Cells. 2000;18(5):360-5.

38. Bussel JB, Hsieh L, Buchanan GR, Stine K, Kalpatthi R, Gnarra DJ, et al. Longterm use of the thrombopoietin-mimetic romiplostim in children with severe chronic immune thrombocytopenia (ITP). Pediatr Blood Cancer. 2014.

\section{Submit your next manuscript to BioMed Central and we will help you at every step:}

- We accept pre-submission inquiries

- Our selector tool helps you to find the most relevant journal

- We provide round the clock customer support

- Convenient online submission

- Thorough peer review

- Inclusion in PubMed and all major indexing services

- Maximum visibility for your research

Submit your manuscript at www.biomedcentral.com/submit
) Biomed Central 